\title{
PERAN PEMBELAJARAN BAHASA INDONESIA TERHADAP PENTINGNYA PENDIDIKAN LINGKUNGAN
}

\author{
Jennyfer Puji Lestari Woi
}

Isu lingkungan pada saat ini tengah banyak diperbincangkan baik dalam sakala Nasional maupun Internasional. Pemberitaan isu lingkungan tidak hanya berbicara mengenai kerusakan lingkungan, namun juga membahas solusi dan pencegahan kerusakan lingkungan. Pencegahan dan upaya penanganan kerusakan lingkungan sudah banyak dilakukan, hal ini dapat dilihat semakin banyaknya organisasi, sukarelawan yang fokus pada tema peduli lingkungan. Tidak hanya berbagai organisasi, tapi upaya pencegahan dan penanganan kerusakan lingkungan juga sudah mulai di terapkan di masyarakat. Kebiasaan menjaga lingkungan dapat membantu mengurangi dampak kerusakan lingkungan, dengan memulai hal kecil yaitu membuang sampah pada tempatnya, membersihkan lingkungan sekitar dan sebagainya. Kebiasaan menjaga lingkungan juga efektif dilakukan di setiap institusi pendidikan, baik dari jenjang sekolah dasar hingga jenjang perguruan tinggi.

Berbagai upaya menjaga lingkungan yang dilakukan di setiap institusi pendidikan sangat beragam. Salah satunya memasukkan materi pentingnya menjaga lingkungan di setiap materi pembelajaran, langkah tersebut dirasa efektif untuk memberikan teori serta pengetahuan dasar mengenai lingkungan.

"Environmental education is a joint effort that is consciously organized to teach or attract human attention about how the natural environment functions and how these humans can manage and protect it".

Nkwetisma dalam Ramadhan (2019:2) mengatakan, pendidikan lingkungan adalah upaya bersama yang secara sadar diselenggarakan untuk mengajarkan atau menarik perhatian manusia tentang bagaimana fungsi lingkungan alam dan bagaimana manusia dapat mengelola dan melindunginya. Bagaimana penerapan pendidikan lingkungan ini agar efektif disebarluaskan ke siswa, yaitu menggunakan salah satu meteri pelajaran di sekolah. 
Salah satu mata pelajaran yang cocok dijadikan media penyebarluasan adalah Bahasa Indonesia. Pendidikan bahasa Indonesia lebih banyak berfokus pada teks, sehingga lewat teks bacaan siswa mampu memahami materi dan teori tentang pentingnya lingkungan. "The aim of environmental education is to make students participate in protecting the environment". Jacobs G M and Cates K dalam Ramadhan (2019:2) mengatakan tujuan dari pendidikan lingkungan adalah untuk membuat siswa berpartisipasi dalam melindungi lingkungan. Peran guru bahasa Indonesia juga sangat penting untuk memobilisasi pendidikan lingkungan ini kedalam pembelajaran bahasa Indonesia. Keikutsertaan siswa dalam menjaga lingungan akan memberikan dampak yang sangat baik, karena sejak usia dini siswa diberikan pengetahuan tentang lingkungan. Hal ini sangat penting untuk mengembangkan pengetahuan tentang lingkungan, kesadaran lingkungan dan perubahan perilaku terhadap lingkungan.

Menurut survei yang telah penulis lakukan terhadap 30 koresponden yaitu guru bahasa Indonesia dengan mengajukan 10 pertanyaan, ternyata didapati bahwa $63,3 \%$ setuju sedangkan $36,7 \%$ lainnya sangat setuju untuk memasukan isu lingkungan ke dalam materi pembelajaran bahasa Indonesia. Sebanyak $70 \%$ para guru setuju bahwa tema lingkungan selalu dijadikan topik dalam setiap jenis teks bahasa Indonesia sedangkan 23,3\% lainnya memilih sangat setuju. Para guru memilih 76,6\% setuju dan 20\% sangat setuju jika materi lingkungan adalah sumber belajar yang mampu mengoptimalkan pencapaian dalam proses pembelajaran bahasa Indonesia. Sebanyak 63,3\% setuju dan $36,7 \%$ sangat setuju bahwa para guru bahasa Indonesia perlu memiliki inovasi dan kreatifitas untuk memanfaatkan materi lingkungan dalam pembelajaran bahasa Indonesia. Pentingnya guru memberikan edukasi pendidikan lingkungan sejak dini sebanyak 53,3\% menyatakan sangat setuju, dan 46,7\% setuju. Hasil yang di dapat ketika diajukann pertanyaan bahwa siswa ditugaskan membuat teks observasi seputar lingkungan yaitu 56,7\% setuju dan $40 \%$ sangat setuju. Pentingnya menjaga lingkungan kelas selama proses 
pembelajaran bahasa Indonesia sebanyak 50\% memilih setuju dan 46,7\% sangat setuju.

Hasil pada survei juga ditemukan bahwa sebanyak 23,3 \% tidak setuju bahwa siswa yang mendapatkan nilai di bawah ketentuan, diharuskan untuk membawa prakarya dari program daur ulang, sedangakan $56,7 \%$ setuju dan $20 \%$ sangat setuju. Sebanyak $80 \%$ setuju bahwa jika materi lingkungan yang dilakukan siswa di luar ruangan, dapat menambah imajinasi siswa secara bebas, sedangkan 16,7\% lainnya sangat setuju. Pertanyaan terakhir yang diajukan pada survei sebanyak 73,3\% setuju jika secara keseluruhan isu lingkungan dapat di gunakan dalam pembelajaran bahasa Indonesia, sedangkan $26,7 \%$ lainnya sangat setuju.

Berdasarkan hasil survei yang dilakukan pada 30 guru bahasa Indonesia, dapat disimpulkan bahwa peran pelajaran bahasa Indonesia sangat berpengaruh pada penyebaran wawasan tentang lingkungan. Diharapkan pelajaran bahasa Indonesia mampu membuka wawasan dan kesadaran siswa tentang pentingnya peduli terhadap lingkungan sekitar. Sebagian besar koresponden setuju bahwa pedidikan lingkungan dapat disandingkan dengan mata pelajaran bahasa Indonesia, khususnya lewat berbagai jenis teks. 


\section{REFERENSI}

Ramadhan, S., Sukma, E., \& Indriyani, V. (2019). Environmental education and disaster mitigation through language learning. IOP Conference Series: Earth and Environmental Science, 314. 